\title{
Sistem Pakar Diagnosa Penyakit Paru-Paru Menggunakan Metode Case Base Reasoning Pada Telegram Bot
}

\author{
Ahmadu Kaju Karo*1, Yufis Azhar ${ }^{2}$, Maskur ${ }^{3}$ \\ 1,2,3Teknik Informatika/Universitas Muhammadiyah Malang \\ agustade46@gmail.com, yufis@umm.ac.id², maskur@umm.ac.id ${ }^{3}$
}

\begin{abstract}
Abstrak
Dalam penelitian ini akan dibahas mengenai pembangunan sebuah aplikasi sistem pakar diagnosa penyakit paru. Dalam mendiagnosa penyakit paru-paru, sistem pakar ini akan menggunakan metode Case Base Reasoning (CBR) pada Bot Telegram. CBR menggunakan kecerdasan buatan (Aritifical Intelegent) yang dalam pemecahan permasalahannya berdasarkan pada knowledge dari kasus-kasus sebelumnya yang ada pada database. Data kasus yang digunakan dalam penelitian ini merupakan data kasus yang diperoleh dari catatan atau rekam medis hasil penanganan pasien atau penderita penyakit paru-paru yang didiagnosa oleh dokter spesialis paru. Bot Telegram merupakan program komputer yang melakukan pekerjaan tertentu secara otomatis untuk meringankan pekerjaan manusia. Terdapat 7 buah kasus lama, dan satu kasus baru yang akan digunakan untuk menghitung nilai kedekatannya dengan kasus lama. Hasilnya sistem akan memberikan keluaran atau output berupa kemungkinan penyakit dan saran pengobatan yang didasarkan pada kemiripan kasus baru degan kasus lama yang ada pada basis pengetahuan (knowledge) yang dimiliki sistem.
\end{abstract}

Kata Kkunci: Sistem Pakar, Penyakit Paru-Paru, Case Base Reasoning, Telegram Bot

\begin{abstract}
In this study will be discussed on the development of an application expert system of diagnosis of pulmonary disease. In diagnosing pulmonary disease lung, expert system it will use the method of Case Base Reasoning (CBR) on Bot Telegram. CBR uses artificial intelligence (Aritifical Intelegent) that in solving the problem based on their knowledge of the case the case of previously existing in the database. The case of the data used in this study was obtained from case data records or medical record results handling patient or sufferer of lung disease that is diagnosed by lung specialist. BOT Telegram is a computer program that performs specific work automatically to ease the work of man. There were 7 cases of old fruit, and one new cases that will be used to calculate the value of proximity to old cases. The result will give the system output or output in the form of the possibility of disease and treatment suggestions based on the similarity of new cases by case long on knowledge base (knowledge) that owned the system.
\end{abstract}

Keywords: Expert System, Lung Disease, Case Base Reasoning, Telegram Bot

\section{Pendahuluan}

Saat ini manusia dan teknologi sudah tidak bisa dipisahkan. Hampir setiap hari semua orang menggunakan alat ini Baik pria, wanita, remaja, maupun anak-anak sudah terbiasa menggunakannya. Dengan alat ini semua pekerjaan manusia menjadi lebih mudah [1].

Inovasi teknologi gadget dari tahun ke tahun sangatlah pesat, diawali dengan ditemukan perangkat yang disebut $\mathrm{Hp}$ (handphone). Ini merupakan perkembangan dari pesawat electronik. Perkembangan $\mathrm{Hp}$ itu sendiri sudah banyak mengalami perubahan, mulai dari ponsel layar kuning yang dilengkapi dengan fitur monophonic dan polyphonic, smartphone yaitu ponsel yang sudah bisa digunakan untuk internet dan sebagainya, munculnya Blackberry merupakan ahkir zaman bagi Nokia, dimana Blackberry dilengkapi dengan fitur BBM yang fungsinya lebih dari sms biasa. Apple merupakan ponsel canggih dan mahal, membuat pengguna Blackberry beralih ke Apple, dan setelah Apple munculah android. Android yang harganya jauh lebih murah dibandingkan dengan ponsel berplatfom IOS [2].

Disamping perkembangan ponsel, perkembangan lainya juga terjadi pada berbagai macam aplikasi pendukung. Salah satunya banyak bermunculan aplikasi chating. E-mail merupakan awal dari semua aktivitas pengiriman pesan instan atau chating. E-mail dibuat 
bertujuan untuk mengganti proses pengirima pesan yang masih bersifat konvensional, namun seiring berjalannya waktu perkembangannyan kinerja e-mai inil dianggap kurang memuaskan, dimana saat melakukan proses pengiriman pesan membutuhkan banyak waktu respon dari penerima pesan tersebut, bahkan pengirim tidak dapat mengetahui dengan jelas apakah pesan yang dikirim sudah terima dan dibaca oleh penerima. Munculah aplikasi-aplikasi chating yang dilengakapi dengan berbagai fitur canggih. Seperti Yahoo messenger, BBM, WhatsApp, Line, We Chat, Kakao Talk, Telegram dan sebagainya [3].

Telegram merupakan sebuah aplikasi multiplatform berbasis cloud yang bersifat gratis dan nearkabel. Aplikasi Telegram ini dapat digunakan pada perangkat telepon seluler maupun perangkat komputer, dimana aplikasi Telegram ini memberikan keamanan tambahan kepada pengguna Telegram yaitu, dalam pengiriman pesan chatting pihak Telegram akan memberlakukan layanan secret chat atau pesan rahasia yang menggunakan metode enkripsi end-to-end. Dengan Telegram pengguna dapat berbagi lebih dari sekedar gambar dan video, tetapi aplikasi ini memungkinkan pengguana untuk mentransfer dokumen foto. Disamping itu, aplikasi ini juga memiliki kelebihan lain, seperti ringan untuk dijalanka, dapat di akses dari berbagai perangkat secara bersamaan, dapat berbagai file dan dokumen dalam ukuran besar, group yang lebih banyak menampung anggota, lebih interaktif dan membuat aplikasi ini beda dengan aplikasi lainya ialah Bot Telegram. Bot Telegram ini dijalankan secara otomatis oleh aplikasi yang dilengkapi dengan fitur Al (Artificial Intellegence) kecerdasan buatan. Bot adalah program computer yang melakukan pekerjaan tertentu secara otomatis [4].

Dengan adanya fitur Bot pada aplikasi Telegram, timbulah suatu pemikiran dimana Bot dapat membantu manusia dalam hal ilmu kesehatan. Paru-paru sebagai pompa satu-satunya dalam sistem pernapasan, dan merupakan organ terpenting dalam kehidupa. Akan tetapi masih begitu banyak orang yang kurang peduli dan mengabaikan kesehatan paru-paru. Sehingga banyak penderita penyakit paru berusia masih sangat muda. Untuk penyakit paru-paru itu sendiri terbagi menjadi berbagai jenis antara lain Tuberkolosis, Bronkitis, PPOK (Penyakit Paru Obstrukti Kronis), dan Pneumonia (Radang Paru) [5].

Jumlah penderita paru-paru yang begitu banyak dibandingkan dengan jumlah dokter spesialis paru-paru, membuat banyak pasien penderita paru harus menunggu dan menghabiskan banak waktu agar dapat berkonsultasi dengan dokter spesialis. Sistem pakar merupakan sebuah sistem dimana sistem tersebut mengambil, menampung serta menerapkan pengetahuan manusia kedalam koputer. Sehingga timbulah suatu ide, dimana penggunaan sistem pakar dalam mendiagnosa gejala awal penyakit paru dengan metode Case Base Reasoning (CCBR). Adanya sistem pakar ini diharapkan dapat membantu masyarakat dalam mendiagnosa gejala awal pasien penyakit paru-paru.

\section{Metode Penelitian}

Pada penelitan ini, metode untuk penyelesaian masalah yang digunakan adalah Case Base Reasoning (CBR). Metode CBR ini digunakan untuk mencari kesamaan kasus baru dengan kasus lama yang ada basic pengetahuan (knowledge) berdasarkan inputan gejala penyakit. Proses selanjutnya adalah, pencarian nilai kedekatan antara kasus menggunakan Algoritma Nearest Neighbor (KNN). Proses ini terdiri dari beberapa tahap, pertama kasus baru diberikan, dan kemudian system akan melakukan pra proses data atau data preprocessing pada kasus baru, setelah itu data hasil akan dibandingkan dengan data yang ada pada knowledge, kemudian mecari kesamaan yang sesuai dengan kata kunci, dan proses selanjutnya melakukan perhitungan dengan algoritma KNN, untuk mencari persentase kemiripan yang paling tinggi, kemudian data dengan kemiripan paling tinggi akan ditampilkan sebagai data hasil diagnose.

\subsection{Metode Case Base Reasoning}

Case Base Reasoning (CBR) menggunakan salah satu bentuk penyelesaian masalah dalam sistem pakar berbasis kasus (knowledge). Pada penyelesaian masalah, dimana basic kasus merupakan kumpulan kasus-kasus dengan denagn solusi yang telah dicapai menggunakan penalaran kecerdasan buatan (Artificial intelligent) yang menitiberatkan penyelesaian masalah yang didasarkan pada knowledge dari kasus-kasus sebelumnya. Secara umum penyelesaian pada metode case base reasoning terdiri dari empat langkah seperti pada Gambar 1.

REPOSITOR, Vol. 2, No. 6, Juni 2020: 711-716 
1. Retrieve (ambil kembali) kasus lama yang mirip dengan kasus baru pada database. Ketika terdapat masalah baru, proses paling pertama yang dilakukan sistem ialah proses retrieve. Diaman dalam proses ini akan dibagi menjadi dua tahapan proses, yaitu tahap pengenalan masalah dan tahap diaman sistem mencarian persamaan masalah didalam database.

2. Reuse (menggunakan) informasi dan pengetahuan dari kasus dalam penyelesaian masalah. Terdapat dua aspek dalam proses reuse, yaitu sistem akan menyeleksi, dan menyalin serta melengkapi informasi yang akan digunakan dimana kasus yang dipilih adalah kasus dengan tingkat kemiripan yang paling tinggi.

3. Revise (revisi) ususlan dari solusi. Pada Tabel 1 tahap ini hasil solusi yang didapat oleh proses reuse dilakukan peninjauan ulang tidak terdapat kesalahan pada permasalahan baru sebelum melangkah ketahap selanjutnya.

Tabel 1. Nilai Tingkat Kemiripan

\begin{tabular}{cc}
\hline Nilai Decimal & Tingkat kemiripan \\
\hline $0.8-1$ & Tinggi \\
$0.4-7.9$ & Sedang \\
$0-0.39$ & rendah \\
\hline
\end{tabular}

4. Retain (menyimpan) solusi dari kasus baru kedalam database. Sistim akan mengindeks, mengintegrasi, dan mengekstrak solusi yang baru. Selanjutnya solusi tersebut akan disimpan ke dalam database (knowledge) untuk digunakan menyelesaikan masalah baru yang akan datang, yang tentunya memiliki kemiripan dengan kasus-kasus lama.

Proses retrive merupakan proses mengambil kembali kasus lama yang memiliki kesamaan dengan kasus baru. Proses pencarian kemiripan kasus baru dengan kasus lama yaitu dengan cara sistem mencocokan gejala yang diinputkan oleh pengguna dengan gejala-gejala yang terdapat didalam database atau basis pengetahuan, menggunakan perhitungan metode Nearest Neighbour (KNN).

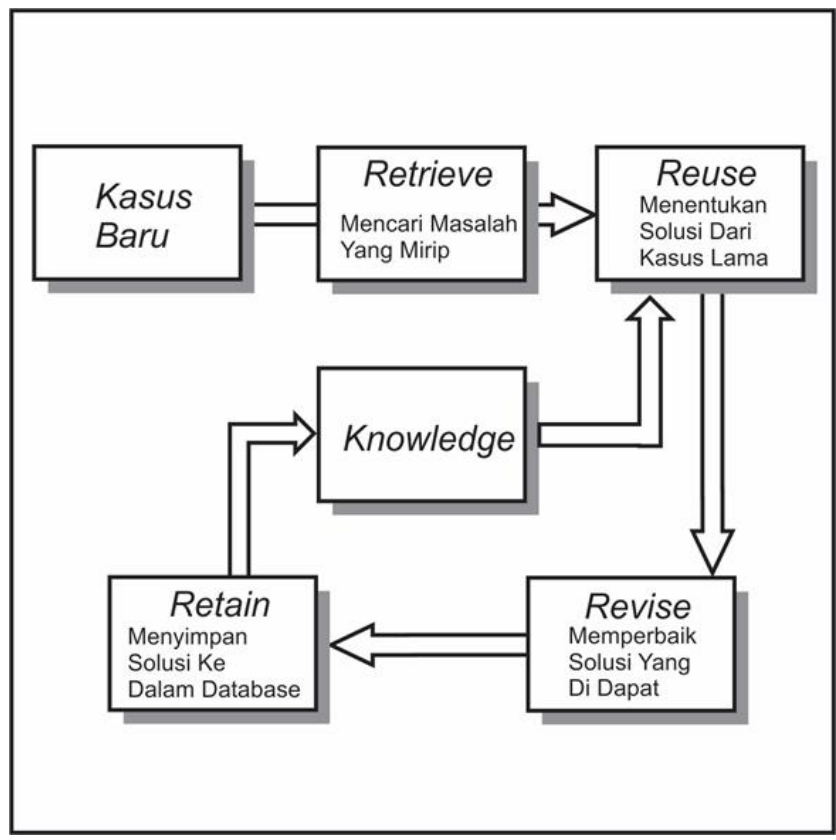

Gambar 1. Alur kerja CBR

\subsection{Algoritma Nearest Neighbor}

Nearest Neighbor adalah penyelesaian masalah denagn melakukan pendekatan untuk mencari kemiripan antara kasus baru dengan kasus yang ada pada database. Dengan menghitung kedekatan antara kasus baru dengan kasus lamayang berdasarkan pada pencocokan bobot nilai atau fitur yang ada. 


$$
\text { Similarity }(\mathrm{T}, \mathrm{S})=\frac{\sum_{i=1}^{n} f(T i, S i) x W i}{W i}
$$

Persamaan 1 menunjukan rumus untuk menghitung jarak anytara kedua kasus. Dalam persamaan kasus baru atau masalah baru $(T)$, kasus yang ada dalam database (S), jumlah atribut untuk setiap kasus (n), atribut individu 1 s.d. $n$ (i), sedangkan (f) fungsi similarity untuk (I) dalam kasus (T) dan kasus (S), dan bobot nilai yang diberikan pada atribut ke-l adalah (W).

\section{Pembahasan dan Hasil}

Dalam pembahasan ini, akan dilakukan proses perhitungan untuk mencari kedekatan kasus lama yaitu kasus yang dijadikan basic pengetahuan (knowledge) yang ada pada sistem dengan kasus baru. Kasus lama berdasarkan data hasil rekam medis pasien yang pernah ditangani oleh dokter spesialis paru, data hasil rekam medis ditunjukan pada Gambar 2.

\begin{tabular}{|l|}
\hline \multicolumn{1}{|c|}{ Kasus : ID 1 } \\
\hline Demam \\
Kelelahan \\
Berat badan turun \\
Keringat malam \\
Nyeri dada \\
Pilek \\
Diagnosa : \\
Penyakit Tuberculusis (TBC) \\
\hline Pengobata : \\
Isoniazid $1 \times 1$ sehari \\
Rifampisin $1 \times 1$ sehari \\
Pirazinamid $1 \times 1$ sehari \\
Etambutol $3 \times 1$ sehari \\
Streptomisin $1 \times 1$ sehari \\
\hline
\end{tabular}

\begin{tabular}{|l|}
\hline \multicolumn{1}{|c|}{ Kasus : ID 2 } \\
\hline Batuk berdahak \\
Sesak Napas \\
Nyeri dada \\
Badan lemas \\
Pilek \\
Diagnosa : \\
Penyakit PPOK (Penyakit Paru \\
Obstructive Khronis) \\
\hline Pengobata : \\
Meptin 2x1 sehari \\
Ambroxol 3x1 sehari \\
Azythomycin 1x1 sehari \\
\end{tabular}

\begin{tabular}{|l|}
\hline \multicolumn{1}{|c|}{ Kasus : ID 3} \\
\hline Batuk berdahak \\
Sesak Napas \\
Demam sedang \\
Badan lemas \\
Pilek \\
Diagnosa : \\
Penyakit Bronchitis \\
\hline Pengobata : \\
Erythromycin $3 \times 1$ sehari \\
Interhistin $3 \times 1$ sehari \\
Asammetelamat $1 \times 1$ sehari \\
Neurodex $1 \times 1$ sehari \\
\end{tabular}

\begin{tabular}{|l|}
\hline \multicolumn{1}{|c|}{ Kasus : ID 4 } \\
\hline Sesak napas \\
Suara mengi \\
Nyeri dada \\
Mudah lelah \\
Iritasi tenggorokan \\
Suara menghilang \\
Bibir dan kuku biru \\
Cemas \\
Batuk terus menerus \\
Diagnosa : \\
Penyakit Asma \\
\hline Pengobata : \\
Obat anti asma dan butuh \\
Penanganan kusus \\
\hline
\end{tabular}

\begin{tabular}{|l|}
\hline \multicolumn{1}{|c|}{ Kasus : ID 5 } \\
\hline Batuk berdahak \\
Sesak Napas \\
Demam tinggi \\
Nyeri dada \\
Nyeri perut \\
Menggigil \\
Pilek \\
Diagnosa : \\
Penyakit Radang Pan \\
(pneumonia) \\
\hline Pengobata : \\
Anti biotik yang tepat \\
Anti batuk \\
Pengencer dahak \\
\hline
\end{tabular}

\begin{tabular}{|l|}
\hline \multicolumn{1}{|c|}{ Kasus : ID 6} \\
\hline Batuk berdarah \\
Nyeri dada \\
Batuk terus menerrus \\
Sesak napas \\
Badan terasa sangat lelah \\
Sakit seluruh tubuh \\
Diagnosa: \\
Penyakit Tumor Paru \\
\hline Pengobata : \\
Perlu tindakan dokter Spesialis \\
\end{tabular}

\begin{tabular}{|l|}
\hline \multicolumn{1}{|c|}{ Kasus : ID7 } \\
\hline Batuk \\
Elergi \\
Sesak napas \\
Dada terasa sesak \\
Pola napas upnormal \\
Diagnosa : \\
Penyakit Paru Kerja \\
(Silicosis, Asbestosis) \\
\hline Pengobata: \\
Perlu tindakan dokter Spesialis \\
\end{tabular}

Gambar 2. Contoh Kasus Penyakit Paru

Langkah selanjutnya adalah, mencari nilai kedekatan atau nilai kemiripan antara kasus lama dengan kasus baru berdasarkan gejala-gejala yang diinputkan pengguna atau user pada Tabel 2. Berdasrkan hasil perhitungan, sistem akan memberikan jawaban berupa hasil diagnosa penyakit yang diderita pasien atau user. Seperti yang ditunjukan pada Gambar 3a dan 3b.

Tabel 2. Gelaja Kasus Baru

\begin{tabular}{c}
\hline Gejala \\
\hline Batuk berdahak \\
Demam tinggi \\
Sesak napas \\
Nyeri dada \\
Nyeri bagian perut \\
Menggigil \\
\hline
\end{tabular}

REPOSITOR, Vol. 2, No. 6, Juni 2020: 711-716 
Kasus baru pada Tabel 2 dan kasus ID 1 dihitung untuk mencari jarak nilai kedekatan:

a. Nilai kedekatan gejala batuk (berdahak dengan berdahak): 1

b. Nilai bobot untuk gejala batuk: 1

c. Nilai kedekatan gejala sesak napas (sesak napas dengan sesak napas): 0

d. Nilai bobot gejala sesak napas: 1

e. Nilai kedekatan gejala demam (tinggi dengan sedang): 0.5

f. Nilai bobot gejala demam: 1

g. Nilai kedekatan gejala nyeri dada (ya dengan tidak): 0

h. Nilai bobot gejala nyeri dada: 0.75

i. Nilai kedekatan gejala keringat malam (tidak dengan ya): 0

j. Nilai bobot gejala keringat malam: 0.5

k. Nilai kedekatan gejala badan lemas (tidak dengan ya): 0

I. Nilai bobot gejala badan lemas: 0.5

$\mathrm{m}$. Nilai kedekatan gejala pilek (tidak dengan ya): 0

n. Nilai bobot gejala pilek: 0.5

o. Nilai kedekatan gejala flu (tidak dengan ya): 0

p. Nilai bobot gejala flu: 0.5

q. Nilai kedekatan gejala nyeri perut (ya dengan tidak): 0

r. Nilai bobot gejala nyeri perut: 0.5

s. Nilai kedekatan gejala menggil (ya dengan tidak): 0

t. Nilai bobot gejala menggigil: 0.5

Nilai kedekatan $=\frac{((a * b)+(c * d)+(e * f)+(g * h)+(i * j)+(k * l)+(m * n)+(o * p)+(q * r)+(s * t))}{b+d+f+h+j+l+n+p+r+t}$

Nilai kedekatan $=\frac{1}{6.25}$

Nilai kedekatan $=0.16$

Langkah diatas adalah cara menghitung jarak nilai kedekatan kasus lama dengan kasus baru berdasarkan gejala-gejala inputan pasien atau user. Hasil selengkapnya ditunjuk pada Tabel 3.

Tabel 3. Hasil Perhitungan Jarak Nilai Kedekatan Kasus Lama Dengan Kasus Baru

\begin{tabular}{ccc}
\hline No & Kasus & Jarak Nilai Kedekatan \\
\hline 1 & ID 1 & 0.16 atau $16 \%$ \\
2 & ID 2 & 0.1 atau $1 \%$ \\
3 & ID 3 & 0.2 atau $2 \%$ \\
4 & ID 4 & 0.12 atau $12 \%$ \\
5 & ID 5 & 0.31 atau $31 \%$ \\
6 & ID 6 & 0.6 atau $6 \%$ \\
7 & ID 7 & 0.11 atau $11 \%$ \\
\hline
\end{tabular}

Tabel 3 adalah hasil perhitungan terhadap 7 kasus lama, hasil perhitungan menunjukanbahwa terdapat kasus yang memiliki nilai kemiripan paling rendah yaitu kasus ID 2 sebesar 0.2 atau $2 \%$. Dan kasus dengan nilai kemiripan paling tinggi yaitu kasus ID 5 sebesar 0.31 atau $31 \%$. Sehingga solusi yang diberikan adalah solusi dengan tingkat nilai kemiripan kasus lama dengan kasus baru yang paling tinggi. Dari perhitungan diatas, kasus yang memiliki nilai kemiripan yang paling tinggi adalah kasus ID 5 , sehingga berdasarkan perhitungan diatas kasus ID 5 yang menjadi saran solusi rekomendasi oleh sistem. Apabila dalam proses retrieve sistem belum bisa memberikan hasil diagnosa, maka sistem akan melakukan kembali proses revise untuk mencari kembali jawaban yang tepat. Namun pada kasus ini sistem pakar sudah berhasil memberikan hasil dianosa yaitu kasus dengan ID 5 yang disarankan oleh sistem.

Semua proses revise telah selesai dilakukan dan sistem telah memberikan rekomendasi solusi yang tepat, selanjutnya sistem akan menyimpan jawaban kasus baru atau rekomendasi solusi kedalam database (knowledge). sehingga nantinya rekomendasi solusi tersebut dapat digunakan dalam penyelesaian masalah untuk kasus-kasus berikutnya, yang tentunya kasus 
tersebut memiliki kemiripan yang sama. Tahap terahkir inilah yang dinamakan dengan proses retain (menyimpan).

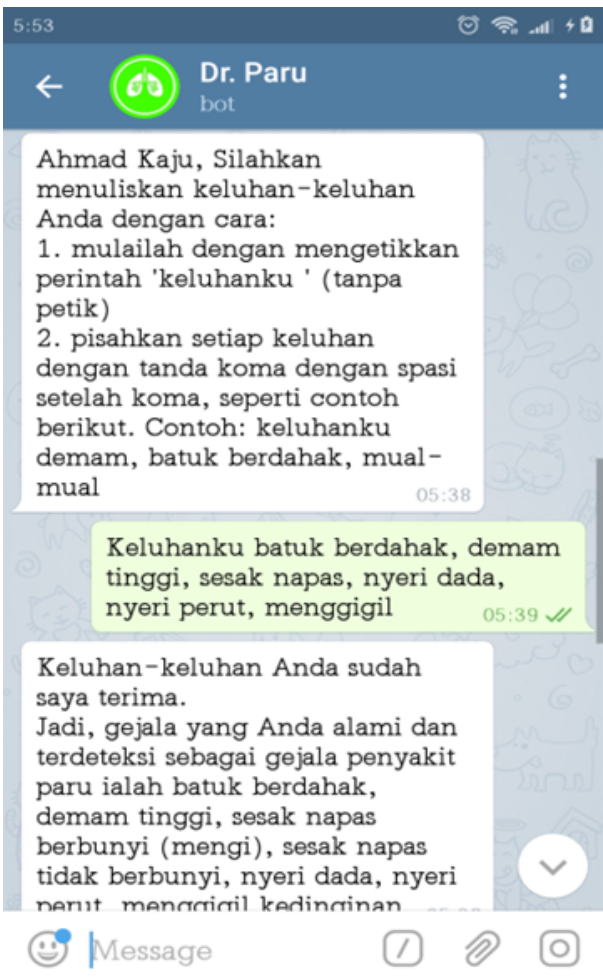

a

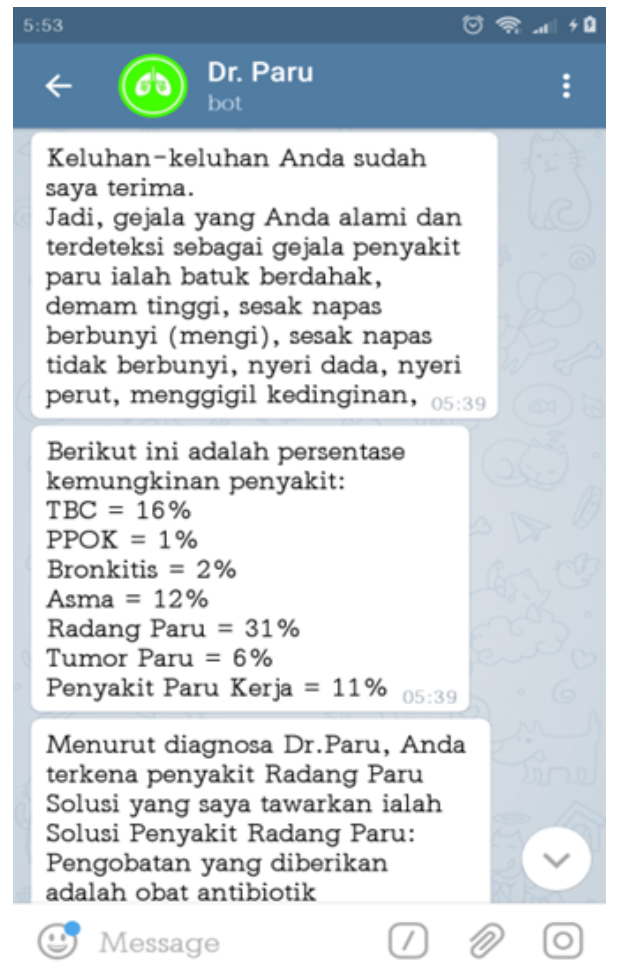

b

Gambar 3. (a) Halaman Kosultasi, (b) Persentase Hasil Diagnosa

\section{Kesimpulan}

Dari hasil penelitian yang dilakukan, kesimpulan dari pembuatan Sistem Pakar Diagnosa Penyakit Paru-Paru Menggunakan Metode Case Base Reasoning Pada Telegram Bot adalah sebagai berikut:

1. Aplikasi Bot Dr. Paru dapat membantu user untuk mendeteksi penyakit paru secara dini, berdasarkan gejala-gejala sakit yang dirasakan.

2. Aplikasi Bot Dr. Paru dapat digunakan sebagai media untuk mengetahui informasi saran, solusi dan cara pola hidup sehat untuk mencegah terjadinya penyakit paru pada seseorang.

3. Aplikasi Bot ini menampilkan nilai kedekatan antara 7 kasus lama terhadap suatu kasus baru dari gejala yang di inputkan oleh seorang pasien. Dari 7 kasus lama ini, akan ada kasus dengan nilai kedekatan paling rendah dan kasus dengan nilai kedekatan paling tinggi sehingga kasus dengan nilai kedekatan yang paling tinggi menjadi saran rekomendasi oleh sistem pakar untuk menentukan jenis penyakit paru yang diderita pasien.

\section{Referensi}

[1] Widiawati dan Sugiman, "Perkembanagn Gadget dan Dampaknya Terhadap Kehidupan" Palembang, 2014.

[2] Cece Nasehudin, "Perkembangan Teknologi Handphone Dalam Kehidupan Masyarakat", 2015.

[3] Mulyadi, "Membuat Aplikasi Untuk Android", Multimedia Center Publishing, Yogyakarta, 2010.

[4] Anggiat Cokrojoyo, Justinus Andjarwirawan, Agustinus Noertjahyana, "Pembuatan Bot Telegram Untuk Mengambil Informasi Dan Jadwal Flim Menggunakan PHP" 2017.

[5] Dr. Jan Hendrokusumo Sp.P. FIZR, Ahli Penyakit Paru. 